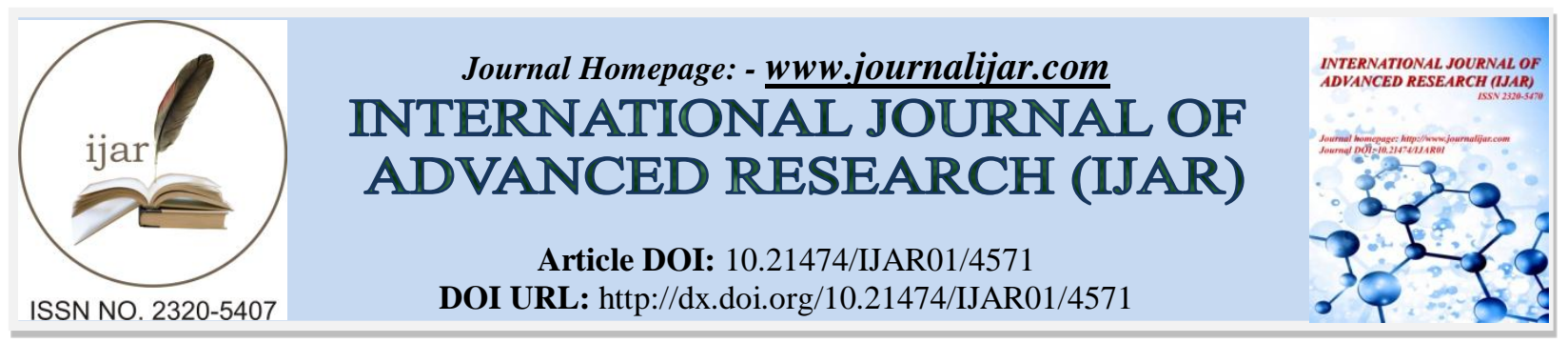

RESEARCH ARTICLE

\title{
A STUDY ON VIDEO GAME PLAYING AMONG CHILDREN AND ADOLESCENT IN TAMILNADU WITH REFERENCE TO CHENNAI.
}

Dr. M. Saravanan.

Department of Visual Communication, Dr. G. R. Damodaran College of Science, Coimbatore, Tamil Nadu, India.

\section{Manuscript Info}

Manuscript History

Received: 22 April 2017

Final Accepted: 24 May 2017

Published: June 2017

Key words:-

Video Game, Children, Adolescent,

Purposive Sampling

\section{Abstract}

This study aims to examine video game playing with children and adolescent on video games usage, socioeconomic strata, gaming habits and preferences. Four hundred and six respondents from various socioeconomic backgrounds participated in the study. The purposive sampling technique was used to obtain data from respondents. This study result reveals that the majority of the participants played video games once in a week and preferred to play evening. besides, video games had played weekends high than weekdays.

Copy Right, IJAR, 2017,. All rights reserved.

\section{Introduction:-}

In the $21^{\text {st }}$ century video game playing increased among children and adolescent in Indian context, because of the ubiquity of video game has emerged social spaces on various platforms such as computers, mobile phones, gaming consoles, websites, etc., particularly, smart phones will lead to increase the video games usage people of all ages. The increases of video game usage decrease their other activities like playing physical games, watching movie and television. The amount of time that children and adolescents are playing videogames has been steadily increasing over the years (Colwell \& Payne, 1997; Subrahmanyam, Kraut, Greenfield, \& Gross, 2000; Anderson, Gentile \& Buckley, 2007). Roberts, et al., (2010) found video game playing among children and adolescent predominant entertainment activities than others. Woodard \& Gridina, (2000) studies revealed some significant $70 \%$ children aged 2-17 have computers in their home and 68\% have video game gadgets. Statista.com (2016) conducted a survey among Indian gamers they stated that 60.44 percentage respondents use a computer or laptop to play video games, 52.74 percentages of respondents reported they didn't participate in online or virtual gaming. In addition, 32.86 percentages of the respondents stated they played first person shooter games. Furthermore, says that digital games industry 49 percentages of the revenue generated by mobile phones than a digital computer, console and social network based gaming. Kantar Indian Market Research Bureau (IMRB) \& Mobile Marketing Association (MMA) Smartphone Usage and Behavior Report in India (2016), the study shows that women spend 2x more time on their smart phones compared to the men - on YouTube and games. The Internet and Mobile Association of India \& IMRB (2016), the report found that entertainment is the main driver of internet consumption.

\section{Review of the literature:-}

Sudha, R. (2012) did a study on psycho physiological of playing violent video games among children in southern Chennai city. This study examined both boys and girls in the age group of 13-18 years who had played violent video games. The purposive sampling technique used to collect the data from the children, who were playing video games at video game parlours/ play stations. The result reveals that children were playing video games at video games center than other places like home, school, etc., and the majority of the children states that they played video games in the evening times and they played shooting game, fighting games and fun games. In addition, playing video 
games did not help their academics or studies. Choo, et al., (2010) examined the video gaming among Singaporean youth. This study found that 83 percentages of children and adolescents played video games. The boys played 22.1 hours per week, compared to 18.2 hours for girls, averaging 20.2 hours per week. Sebastian, T. (2010) examined an impact of computer animation on child and adolescent development. The survey collected 687 school students from three major cities (Cochin, Calicut and Trivandrum) in Kerala. The result shows that computer animation game may influence violence and desensitize the children.

\section{Methodology:-}

Objectives of the Study:-

- To study the video game usage among children and adolescent in Chennai.

- To study the socioeconomic status of video game users.

\section{Participants:-}

Survey data were collected from four hundred and six $(\mathrm{M}=13.68, \mathrm{SD}=2.39)$ respondents from various socioeconomic backgrounds from Chennai metropolitan cities and its suburban areas. This survey was conducted video game playing arcade, gaming lounge, internet cafeteria and video game play station.

\section{Instruments:-}

The questionnaire was aimed at collecting data regarding demographic characteristics of the participants and academic level, and their socioeconomic status (SES) that include family monthly income, parents' occupation, owning a computer and video game consoles, video game playing habits such as amount of time, place of access, time of playing, frequency of play and whom do tend to play.

\section{Sampling Method:-}

This study used a 'purposive sampling' in the non-probability category. The sample consist of the whole population of school goers, diploma students, school discontinued and illiterates who had played video games children and adolescent both male and female in the age group of 9 to 17 years.

\section{Procedure:-}

The purpose of the study was clarified to the respondents and made clear that participation was voluntary; the data were collected from March to June 2013. Individuals were informed that all information was anonymous and confidential.

\section{Results and Discussions:- Demographic:-}

The gender distribution of the respondents was $88.2 \%$ male $(n=358)$ and $11.8 \%(n=58)$ female. Since the samples were taken in the video game playing places, girls coming to play these places were comparatively lesser. Because of India is a patriarchal society, parents may not permit girls to play video games in gaming arcade, internet cafeteria and play centre. In addition, a total of the respondents, $61.6 \%$ city $(n=250)$ and $38.4 \%(n=156)$ suburban areas. Particularly, the lack of video games parlour in suburban areas, for the reason that suburban was comparatively lesser. A total of the participants nearly $(92.1 \%)$ were school students compared to other educational divisions.

Table 1:- Frequency distribution of the participants demographic.

\begin{tabular}{|l|l|l|}
\hline Gender & Frequency & Percentage \\
\hline Male & 358 & 88.2 \\
\hline Female & 48 & 11.8 \\
\hline Total & 406 & 100.0 \\
\hline \multicolumn{2}{|c|}{ Place of Residence } \\
\hline Place & Frequency & Percentage \\
\hline City & 250 & 61.6 \\
\hline Suburban & 156 & 38.4 \\
\hline Total & 406 & 100.0 \\
\hline \multicolumn{2}{|c|}{ Educational Qualification } \\
\hline Educational Level & Frequency & Percentage \\
\hline Going to school & 374 & 92.1 \\
\hline
\end{tabular}




\begin{tabular}{|l|r|r|}
\hline School Discontinued & 7 & 1.7 \\
\hline Diploma & 24 & 5.9 \\
\hline Illiterate & 1 & 0.2 \\
\hline Total & 406 & 100.0 \\
\hline
\end{tabular}

Socioeconomic Strata:-

In this study, the major percentages of the participant's fathers were working and (41.4\%) of the participant's mother was a house wife. Table 2 shows that $24.9 \%$ of the sample monthly income were Rs.10000/- to 20000/-. The present study, the significance of the sample monthly income was Rs. 20000/- and below. Incomes play an important role for children and adolescent where as may play at home, arcade, video game lounge or video game play station.

Table 2:- Frequency distribution of the children and adolescent based on Socioeconomic Strata.

\begin{tabular}{|c|c|c|c|c|}
\hline \multirow[t]{2}{*}{ ParentsOccupation } & \multicolumn{2}{|c|}{ Father } & \multicolumn{2}{|c|}{ Mother } \\
\hline & Frequency & Percentage & Frequency & Percentage \\
\hline Not working & 5 & 1.2 & 168 & 41.4 \\
\hline Working & 390 & 96.1 & 231 & 56.9 \\
\hline Retired & 2 & 0.5 & 3 & 0.7 \\
\hline Expired & 9 & 2.2 & 4 & 1.0 \\
\hline Total & 406 & 100.0 & 406 & 100.0 \\
\hline \multicolumn{5}{|c|}{ Monthly Family income } \\
\hline Income & \multicolumn{2}{|c|}{ Frequency } & \multicolumn{2}{|c|}{ Percentage } \\
\hline Below 10000 & \multicolumn{2}{|c|}{75} & \multicolumn{2}{|c|}{18.5} \\
\hline $10001-20000$ & \multicolumn{2}{|c|}{101} & \multicolumn{2}{|c|}{24.9} \\
\hline $20001-30000$ & \multicolumn{2}{|c|}{79} & \multicolumn{2}{|c|}{19.5} \\
\hline $30001-40000$ & \multicolumn{2}{|c|}{56} & \multicolumn{2}{|c|}{13.8} \\
\hline $40001-50000$ & \multicolumn{2}{|c|}{40} & \multicolumn{2}{|c|}{9.9} \\
\hline Above 50000 & \multicolumn{2}{|c|}{55} & \multicolumn{2}{|c|}{13.5} \\
\hline Total & \multicolumn{2}{|c|}{406} & \multicolumn{2}{|c|}{100.0} \\
\hline
\end{tabular}

\section{Video game playing:-}

The majority of the participants $(94.3 \%)$ reported playing video games at least once a week with $41.1 \%$ of the respondents reported owning computer / laptop and $25.1 \%$ of respondents stated owning gaming consoles like PS 2 , PS 3, PSP, X BOX, X BOX 360 and WII. Also the significant percentage $58.4 \%$ of the participants reported video game playing started at the age range from 7-10 years. In this study, a major percentage of the children and adolescent $60.8 \%$ had played video games in the evening. Nearly $87.4 \%$ of the respondents reported they had played video games in weekdays and all of the respondents reported that they had played on weekends. Playing video games on the weekends might be one of the reasons that they could break away from academics and escape from their parent's supervision.

Table 3:- Frequency distribution of the children and adolescent by Video game playing

\begin{tabular}{|c|c|c|c|c|}
\hline How often play video games & \multicolumn{2}{|c|}{ Frequency } & \multicolumn{2}{|c|}{ Percentage } \\
\hline Every day & \multicolumn{2}{|c|}{208} & \multicolumn{2}{|c|}{51.2} \\
\hline 5 or more times per week & \multicolumn{2}{|c|}{47} & \multicolumn{2}{|c|}{11.6} \\
\hline 2 to 4 times per week & \multicolumn{2}{|c|}{99} & \multicolumn{2}{|c|}{24.4} \\
\hline Once a week & \multicolumn{2}{|c|}{29} & \multicolumn{2}{|c|}{7.1} \\
\hline Once in fifteen days & \multicolumn{2}{|c|}{8} & \multicolumn{2}{|c|}{2.0} \\
\hline Once a month & \multicolumn{2}{|c|}{15} & \multicolumn{2}{|c|}{3.7} \\
\hline Total & \multicolumn{2}{|c|}{406} & \multicolumn{2}{|c|}{100.0} \\
\hline \multirow{2}{*}{$\begin{array}{c}\text { Amount of time spent a day } \\
\text { playing video games }\end{array}$} & \multicolumn{2}{|c|}{ Week days } & \multicolumn{2}{|c|}{$\begin{array}{c}\text { Week ends } \\
\end{array}$} \\
\hline & Frequency & Percentage & Frequency & Percentage \\
\hline Less than hour & 144 & 35.5 & 40 & 9.9 \\
\hline $1-2 \mathrm{hrs}$ & 123 & 30.3 & 67 & 16.5 \\
\hline $2-3 \mathrm{hrs}$ & 32 & 7.9 & 94 & 23.2 \\
\hline
\end{tabular}




\begin{tabular}{|c|c|c|c|c|}
\hline $3-4 \mathrm{hrs}$ & 15 & 3.7 & 49 & 12.1 \\
\hline $4-5 \mathrm{hrs}$ & 22 & 5.4 & 50 & 12.3 \\
\hline More than 5 hrs & 19 & 4.7 & 106 & 26.1 \\
\hline Do not play & 51 & 12.6 & 0 & 0 \\
\hline Total & 406 & 100.00 & 406 & 100.00 \\
\hline
\end{tabular}

Video game preferences:-

In this study, a major percentage of respondents were $49.8 \%(\mathrm{n}=202)$ and $45.1 \%$ (183) preferably played in the video games at home and video game centre like play zone, parlor, gaming lounge. Playing video games with friends in the video game centre was entertaining and socialization. Also video games playing fostered team building and group competitively. A substantial percentage (58.6\%) of the children and adolescent reported that they had played video games with their friends than parents and siblings. In addition, computer, mobile phones and gaming consoles they had preferred to play video games more compared to other gaming devices like arcade and handheld. The major samples reported that the most favorite video games are Grand Theft Auto, WWE-F/Smack Down, Call of Duty and Need for Speed.

Table 4:- Frequency distribution of the children and adolescent by Video game preferences

\begin{tabular}{|c|c|c|c|c|}
\hline $\begin{array}{c}\text { hom do you play video } \\
\text { game }\end{array}$ & rrequency & Percentage & $\begin{array}{c}\text { Prefer platforms to play } \\
\text { video games }\end{array}$ & Percentage \\
\hline \begin{tabular}{|c|} 
Alone \\
\end{tabular} & 86 & 21.2 & Computer & 80.8 \\
\hline Friends & 238 & 58.6 & Mobile phone & 79.3 \\
\hline Siblings & 68 & 16.7 & Console & 75.6 \\
\hline Father & 10 & 2.5 & Handheld & 53.7 \\
\hline Mother & 2 & 0.5 & Online(MMORPG) & 43.1 \\
\hline Stranger & 2 & 0.5 & Arcade & 15.0 \\
\hline Total & 406 & & 100.0 & \\
\hline \multicolumn{5}{|c|}{ Favorites video games } \\
\hline \multicolumn{3}{|c|}{ Game title } & Frequency & Percentage \\
\hline \multicolumn{3}{|c|}{ Grand Theft Auto } & 89 & 21.9 \\
\hline \multicolumn{3}{|c|}{ WWE-F/Smack Down } & 83 & 20.4 \\
\hline \multicolumn{3}{|c|}{ Call Of Duty } & 44 & 10.8 \\
\hline \multicolumn{3}{|c|}{ Need For Speed } & 27 & 6.7 \\
\hline
\end{tabular}

\section{References:-}

1. Anderson, C. A., Gentile, D. A., \& Buckley, K. (2007). Violent video game effects on children and adolescents: Theory, research, and public policy. New York: Oxford University Press.

2. Choo, H., Gentile, D. A., Sim, T., Li, D. D., Khoo, A., \& Liau, A. K. (2010). Pathological video-gaming among Singaporean youth. Annals Academy of Medicine Singapore, 39(11), 822-829.

3. Colwell, J., \& Payne, J. (1997). Negative correlates of computer game play in adolescents. British Journal of Psychology, 91(3) , 295-310.

4. Roberts, D.F., Foehr,U.G., \& Rideout,V.J. (2010). Generation $\mathrm{M}^{2}$ : Media in the lives of 8-18 year olds. Henry J. Kaiser Family Foundation.

5. Sebastian, T. (2010). A Study On The Impact Of Computer Animation On Children In Three Cities Of Kerala. Dissertation.

6. Subrahmanyam, et al., (2000). The impact of home computer use on children's activities and development. The Future of Children: Children and Computer Technology, 10(2), 123-144.

7. Sudha, R. (2012) The effect psycho physiological of playing violent video games among children. Dissertation.

8. Woodard, E. H., \& Gridina, N. (2000). Media in the home 2000: The fifth annual survey of parents and children (Survey Series No. 7). Philadelphia, PA: University of Pennsylvania, Annenberg Public Policy Center.

\section{Websites:-}

1. Internet and Mobile Association of India \& Kantar Indian Market Research Bureau (2016). Internet in India. Retrieved April 2017, from http://bestmediainfo.com/wp-content/uploads/2017/03/Internet-in-India-2016.pdf

2. Kantar Indian Market Research Bureau \& Mobile Marketing Association (2016). Smartphone Usage and Behavior Report in India Retrieved May 2017, from 
3. http://www.mmaglobal.com/files/documents/mma_kimrb_smartphone_report_overview.pdf

4. https://www.statista.com/statistics/534159/digital-games-revenue-share-category-india/

5. https://www.statista.com/statistics/562403/india-types-of-video-computer-games-played/

6. https://www.statista.com/statistics/562354/india-online-and-virtual-gaming-participation/ 